\title{
Um Pouco de Chico Xavier Por Suely Caldas Schubert
}

\author{
A BIT OF CHICO XAVIER BY SUELY CALDAS SCHUBERT
}

\author{
UN POCO DE CHICO XAVIER POR SUELy CALDAS SCHUBERT
}

Brasil Fernandes de Barros*

\begin{abstract}
RESUMO
Entrevista realizada em 17 de agosto de 2019, durante o $3^{\circ}$ Congresso da Aliança Municipal Espírita de Belo Horizonte, com a médium e escritora mineira Suely Caldas Schubert. Essa entrevista trata do convívio de Suely Caldas com o famoso médium mineiro Francisco Cândido Xavier, com ênfase na obra Testemunhos de Chico Xavier, na qual faz contato com a intimidade dele, trazendo a público as cartas pessoais que ele escrevia a Wantuil de Freitas, Presidente da Federação Espírita Brasileira na época. Esse registro é parte da nossa pesquisa de Doutorado no Programa de Pós-graduação em Ciências da Religião da PUC Minas intitulado Na Intimidade Do Coração: a mística na vida e obra de Chico Xavier.
\end{abstract}

Palavras-chave: Chico Xavier. Mística. Suely Caldas Schubert.

\begin{abstract}
An interview conducted on August 17, 2019, during the 3rd Congress of the Aliança Municipal Espírita de Belo Horizonte, with the medium and writer from Minas Gerais State in Brazil, Suely Caldas Schubert. This interview deals with Suely Caldas' relationship with the famous medium from the same State, Francisco Cândido Xavier, with emphasis on the book Testemunhos de Chico Xavier, in which she made contact with his intimacy, bringing to light personal letters he wrote to Wantuil de Freitas, the President of the Brazilian Spiritist Federation at that time. This record is part of my doctoral research in the Graduate Program in Religious Studies at PUC Minas titled Na intimidade do coração: a mística na vida e obra de Chico Xavier.
\end{abstract}

Keywords: Chico Xavier. Mysticism. Suely Caldas Schubert.

\section{RESUMEN}

Entrevista realizada el 17 de agosto de 2019, durante el III Congreso de la Alianza Espírita Municipal de Belo Horizonte, con la médium y escritora de Minas Gerais, Suely Caldas Schubert. Esta entrevista trata de la convivencia de Suely Caldas con el famoso médium de Minas Gerais, Francisco Cândido Xavier, con énfasis en la obra Testemunhos de Chico Xavier, en que ella hace contacto con su intimidad, sacando a la luz las cartas personales que él escribió a Wantuil de Freitas, en la época presidente de la Federación Espiritista Brasileña. Este informe es parte de nuestra investigación de doctorado en el programa de postgrado en Ciencias de la Religión de la PUC Minas, titulada, Na intimidade do coração: a mística na vida e obra de Chico Xavier.

Palabras Clave: Chico Xavier. Mística. Suely Caldas Schubert.

\footnotetext{
*Mestre e doutorando em Ciências da Religião pelo Programa de Pós-graduação em Ciências da Religião da Pontifícia Universidade Católica de Minas Gerais - PUC Minas. Brasil. Bolsista CAPES. ORCID: oooo-Ooo25285-4871. E-mail:brasil@netinfor.com.br
} 
Em março de 2019 iniciamos o nosso projeto de pesquisa de doutorado, no Programa de Pós-graduação em Ciências da Religião da PUC Minas, intitulado NA INTIMIDADE DO CORAÇÃO: a mística na vida e obra de Chico Xavier. Essa pesquisa pretende identificar se seria possível estabelecer, a partir da vida e da obra do famoso médium mineiro Chico Xavier, uma relação com as principais características de grandes místicos da história, identificando a presença de uma mística voltada para a prática do amor e da caridade, e se ela guarda influências que vão além do Espiritismo de Allan Kardec.

Embora, segundo relatos obtidos por pessoas de sua convivência, Chico Xavier não acreditasse na sua condição de místico, tentaremos provar tal hipótese, através de pesquisas bibliográficas, documentais e de entrevistas com pessoas que tiveram um contato pessoal com o médium mineiro. Essas entrevistas têm por fim dar voz a Chico Xavier, oferecendonos informações relevantes acerca de seus pensamentos e trazendo, sempre que possível, seus pontos de vista. Isso é importante, na medida que, na maioria das vezes, muito do que é atribuído como sua fala tem sido reportado como sendo as vozes dos espíritos através de sua psicografia.

Um dos registros históricos de cunho mais pessoal foi relatado na obra da médium e escritora mineira Suely Caldas Schubert intitulada Testemunhos de Chico Xavier (2010), na qual a autora entra em contato com a intimidade dele, trazendo a público as cartas pessoais que ele escrevia a Wantuil de Freitas, Presidente da Federação Espírita Brasileira na época. Essas cartas não eram as dos chamados espíritos, mas, sim, do cidadão Francisco Cândido Xavier, nas quais ele relatava suas lutas e dores na condução da missão espírita que assumiu para si mesmo. Dessa forma, em 17 de agosto de 2019, durante o $3^{\circ}$ Congresso da Aliança Municipal Espírita de Belo Horizonte, com o fim de atender aos objetivos de nossa pesquisa, gravamos uma entrevista ${ }^{1}$ com Suely Caldas Schubert.

Nascida em um berço espírita, em 9 de dezembro 1939, em Carangola, Minas Gerais, ainda na sua infância, a escritora passou a residir em Juiz de Fora, no mesmo estado. Schubert é escritora, médium e consagrada oradora, e tem se dedicado, no decorrer de sua vida, especialmente ao estudo da mediunidade e à divulgação do Espiritismo. Foi uma das fundadoras da Sociedade Espírita Joana de Angelis, em Juiz de Fora, e, desde 1971, trabalha na Aliança Municipal Espírita daquela cidade, onde é Diretora do Departamento de assuntos de Mediunidade. É autora de dezessete livros, dos quais destacamos: Dimensões Espirituais

\footnotetext{
${ }^{1}$ Entrevista concedida de acordo com o TCLE (Termo de Consentimento Livre Esclarecido) sob número de registro CEP: CAAE: (16654819.7.0000.5137).
} 
do Centro Espírita (2012); Divaldo Franco: uma vida com os Espíritos (2006a); Obsessão/Desobsessão: Profilaxia e Terapêutica Espíritas (1999); Os Poderes da Mente (2010); O Semeador de Estrelas (1989); Testemunhos de Chico Xavier (2010) e Transtornos Mentais: uma leitura espírita (2006b).

A seguir, a entrevista com Suely Caldas Schubert:

\section{Como a senhora conheceu Chico Xavier?}

O meu conhecimento a respeito de Chico Xavier vem de muito antes de ir visitá-lo pela primeira vez. Sendo de família espírita, meu pai sempre esteve lendo e estudando, procurando ter um conhecimento maior da Doutrina, embora tenha feito somente até o terceiro ano primário. Mas ele era um leitor infatigável, e foi assim que tomei contato com os livros de Chico e outros mais da Doutrina.

Quando eu tinha 9 anos, eu comecei a ler os primeiros livros espíritas, que, no caso, foram alguns romances de um autor chamado Fernando do Ó. Preciso dizer que sou uma leitora compulsiva... Li todos os livros do meu pai, mesmo os não espíritas, coleções de vários autores. Minha vida é ler, depois, escrever.

E comecei lendo os romances, para depois começar a ler as obras doutrinárias, inclusive a própria Codificação e isso suscitou em mim - à medida que eu fui lendo, logo depois, a obra de André Luiz, Emmanuel - e, a partir daí, a vontade de conhecer o Chico. Eu tinha a impressão de que eu já o conhecia, que era alguma coisa assim muito familiar a mim, o que depois foi por ele confirmado. E então, no ano de 1960, resolvemos ir a Uberaba para o conhecer pessoalmente.

\section{A senhora tinha quantos anos nessa época?}

Eu estava com 21 anos. Eu já era casada já tinha uma filha, de poucos meses, caseime aos 18 anos.

Antes eu vou contar o motivo pelo qual eu fui a Uberaba. Havia um motivo maior, eu já estava psicografando, porque a minha mediunidade despontou mesmo aos 16 anos de idade, quando comecei aplicar passes, no Centro Espírita Ivon Costa, de Juiz de Fora. Mais adiante, com 19 anos, já casada, sentindo presenças espirituais muito intensas, comecei a psicografar, em casa mesmo. Porque nós fazíamos o culto do lar, eu, o meu marido, meus pais, e nesse momento às vezes eu tinha vontade de escrever e comecei a psicografar, logo 
depois passamos a fazer uma reunião em nossa casa, e já com a filhinha de poucos meses, numa reuniãozinha pequena. Alguns Espíritos amigos escreviam, eram mensagens instrutivas. Posteriormente comecei a receber mensagens de um espírito que assinava o nome de Militão Pacheco. Eu não sabia quem era! Achei o nome muito estranho, mas assinava, porque a mensagem era muito boa!

Quando iniciei, as páginas psicografadas vinham com título, com conteúdo e com assinatura. Mas, Militão Pacheco, este chamou muito a minha atenção. Alguns dias depois, folheando um dos livros do meu pai com mensagens psicografadas por Chico Xavier, eu descobri uma de autoria de Militão Pacheco. Fiquei preocupada com aquilo, pois pensei que deveria ter lido tal livro e aquele nome teria ficado no meu subconsciente, por isso é que assinava Militão Pacheco... mas, vai ver que não é ele. São as dúvidas do médium iniciante, foi por isso que fomos a Uberaba.

Naquela época, Chico atendia na Comunhão Espírita Cristã de Uberaba, e sabendo disso fomos para lá. Mas combinamos que seríamos os últimos da fila, para poder ter um pouco mais tempo e não ficarmos naquela pressa de ter pessoas ainda para serem atendidas, o que faz com que a criatura comece a resumir muito a conversa, por isso ficamos por último.

Então, a poucos metros de distância do Chico, ele me olhou e disse: "Suely, minha filha, tanto tempo esperei que vocês viessem", e muito surpresa e emocionada, mal conseguia andar, cheguei perto dele que me abraçou e disse: "Eu não sabia que vocês estavam aqui, nisto eu vi entrar o nosso doutor Militão Pacheco e abraçar uma pessoa, quando eu olhei, era você!” Meu Deus, eu já estava com todas as respostas! É, não precisava nem perguntar mais nada! Aí eu fiquei assim, perdi a fala. A gente nem consegue falar, né!

\section{Perdeu a fala porque o Chico nunca tinha visto a senhora?}

É, e eu nunca o tinha visto pessoalmente! É, então é... é um impacto aquela emoção!

E ele foi muito carinhoso também com o meu marido, foi uma coisa muito interessante. E daí em diante, ele começou a orientar a minha mediunidade. E que eu deveria mesmo psicografar diariamente e que, então, eu estava tendo uma proteção do doutor Militão Pacheco², um médico homeopata que fez parte da Federação Espírita de São Paulo.

\footnotetext{
${ }^{2}$ Dr. Augusto Militão Pacheco (1866 - 1954) foi um médico homeopata e espírita com forte envolvimento na fundação da Federação Espírita do Estado de São Paulo (FEESP), já falecido à época relatada pela entrevistada.
} 


\section{A senhora visitava o Chico regularmente? Como era? Quantas vezes esteve com ele até ele partir?}

Olha, não era regularmente, porque logo depois, em 1960, eu tive o segundo filho. E com isso havia muita dificuldade de viajar, tínhamos dificuldades financeiras e isso também nos impedia. Nós fomos de ônibus para lá a primeira vez.

Fomos depois de carro também, nas outras oportunidades. Eu passava anos sem ir, mais de 2, 3 anos, porque não tinha condição. Porém, o Martins Peralva ${ }^{3}$, nosso amigo residente em Belo Horizonte, combinou comigo que quando Chico Xavier viesse de Uberaba para Pedro Leopoldo ele me avisaria ... porque como ele havia mudado há pouco tempo ${ }^{4}$, e estava indo e vindo para Pedro Leopoldo, para resolver problemas familiares, e muitas coisas, portanto...

5. Parece que ele tinha muitos problemas com a família, ele chegou a relatar alguma uma vez? Ele chegou a lhe falar desses problemas?

Não, não tínhamos esse tipo de conversa.

Foi quando o Martins Peralva falou comigo: “Quando ele vier a Pedro Leopoldo eu te aviso, para evitar de vocês irem a Uberaba, porque é muito longe e Pedro Leopoldo fica perto de Belo Horizonte.”

Na época que eu ia, havia muita aproximação e Chico me fez uma dedicatória (IMAGEM 1) que eu coloquei depois no meu livro Testemunhos de Chico Xavier, que até hoje me emociona, porque dá para notar o quanto havia de estima por parte dele, não é? Ele menciona isso.

\footnotetext{
${ }^{3}$ José Martins Peralva Sobrinho (1918 - 2007) foi escritor espírita e Presidente da União Espírita Mineira.

${ }^{4}$ Chico Xavier mudou da cidade de Pedro Leopoldo para Uberaba em 1959, por questões de ordem familiar.
} 


\section{Imagem 1: Dedicatória feita a Suely Caldas Schubert pelo livro Testemunhos de Chico Xavier}

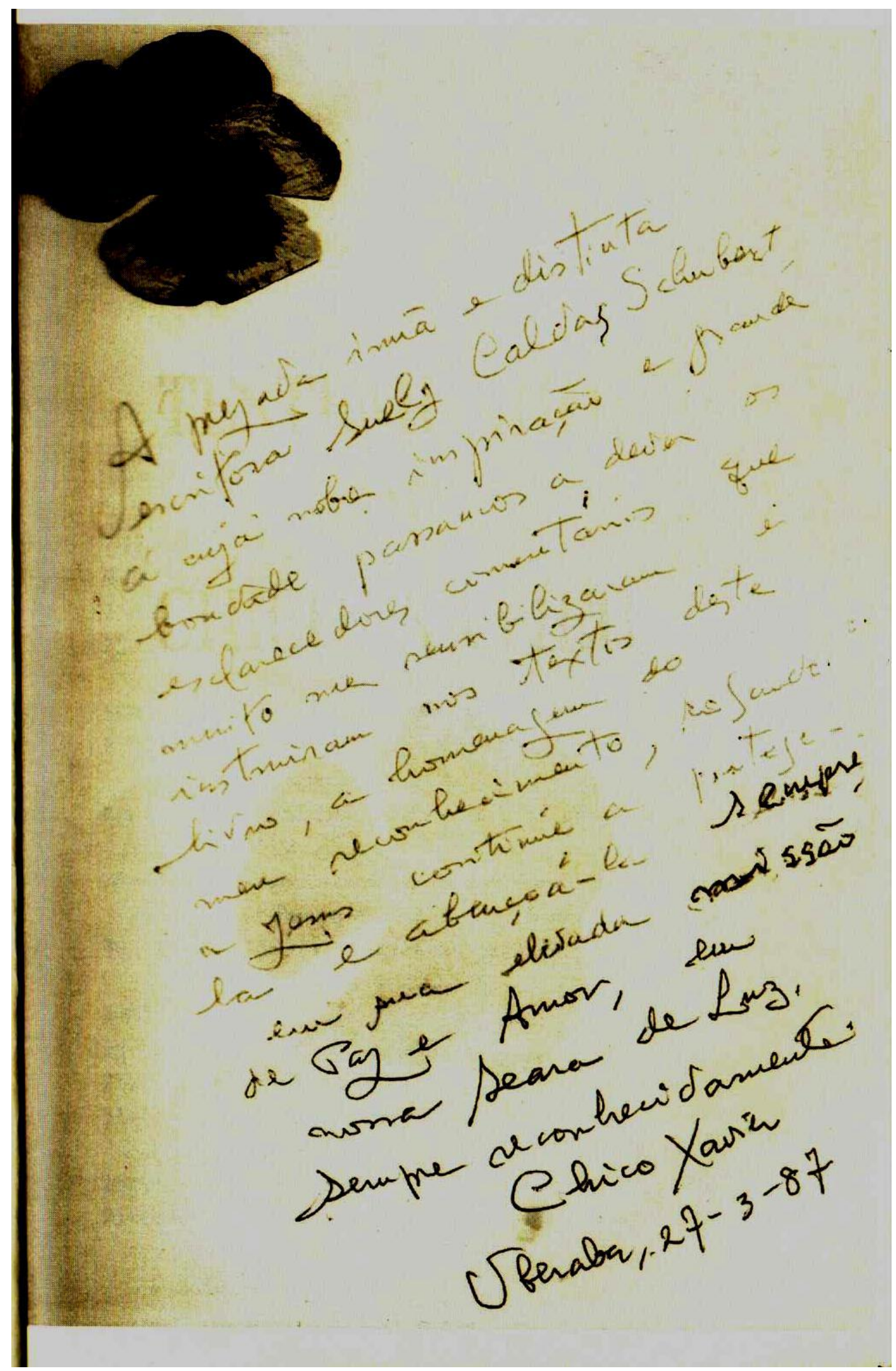

Fonte: SCHUBERT, 2010, p. 5 


\section{Transcrição da dedicatória:}

A prezada irmã e distinta escritora Suely Caldas Schubert a cuja nobre inspiração e grande bondade passamos a dever os esclarecedores comentários que muito me sensibilizaram e instruíram nos textos deste livro, a homenagem do meu reconhecimento, rogando a Jesus continue a protegê-la e abençoá-la sempre em sua elevada missão de Paz e Amor, em nossa Seara de Luz.

Sempre reconhecidamente,

Chico Xavier

Uberaba, 27-3-87

\section{Sobre o livro Testemumhos de Chico Xavier, quando e como a senhora contou para ele do que estava escrevendo sobre as cartas?}

Quando em 1980, eu lancei o meu livro Obsessão/Desobsessão, pela FEB, o presidente era Francisco Thiesen, e nós ficamos muito amigos. Como a FEB aprovou o meu primeiro livro, Thiesen teve a ideia de me convidar para escrever os comentários da correspondência do Chico. O Thiesen me convidou para ir à FEB para me apresentar uma proposta. Era uma pequena reunião, na qual estavam presentes, além dele, o Juvanir de Souza e o Zeus Wantuil. Fiquei ciente que me convidavam para escrever um livro com os comentários da correspondência entre Chico Xavier e o então presidente da FEB, Wantuil de Freitas ${ }^{5}$, desencarnado há bem tempo, pai do Zeus Wantuil, que ali estava presente. Zeus, cuidadosamente, catalogou aquelas cartas e conseguiu fazer delas um conjunto bem completo no formato de uma apostila, que, então, me entregaram.

\section{E eles se correspondiam muito?}

Sim, bastante, quase diariamente.

Então eu comecei a ler, sob intensa emoção, pela importância dos conteúdos nos textos do Chico. É preciso esclarecer que, ao escrever, notei que deveria fazer uma seleção das cartas, assim, no livro consta uma parte, a maior parte, porque ficaria grande demais e poderia ser repetitivo também. Nessa época comecei a ir ao Chico com muita frequência,

\footnotetext{
${ }^{5}$ Antônio Wantuil de Freitas (1895 - 1974) foi um farmacêutico brasileiro. Foi presidente da Federação Espírita Brasileira de 1943 a 1970.
} 
porque, quando o Presidente da FEB, o Francisco Thiesen, me convidou e expôs qual era o programa, eu disse para ele assim: "Bem, mas eu preciso, primeiro, ir ao Chico para pedir permissão, por que é a correspondência, é uma correspondência particular." Embora tenha ali muitos ensinamentos contidos em todos aqueles momentos em que ele escrevia para Wantuil de Freitas, eu gostaria então de ir lá para primeiro, pedir permissão.

\section{Seria correto dizer que o Chico nunca pensou que essas cartas iriam a público?}

Sim, é correto. É certo, porque ao saber que iria ser condensado em um livro o teor das cartas que enviara a Wantuil - logicamente a parte doutrinária, que tivemos o cuidado de selecionar -, Chico foi logo dizendo que elas não teriam nada que tivesse valor suficiente para constar de um livro. Mas insistimos, até o momento em que ele disse: "Bem, se a FEB crê que as cartas têm algum valor, então estou de acordo e dou a permissão." Marquei uma data, através do Eurípedes ${ }^{6}$, e fui, com amigos.

\section{Ele achava que não tinha importância?}

É, ele não achou importante. Dizia que não tinha valor algum doutrinariamente falando. Esclareci para ele o que tinha sido selecionado, e que não ia expor tudo, apenas o que era a parte doutrinária, evitando qualquer coisa pessoal, que eu achasse que não seria oportuno. Não que fosse inconveniente, porque ele não fala nada inconveniente, é se não fosse oportuno. Ele deu a permissão ali naquele momento, mas depois a FEB enviou um documento, porque tinha que fazer isso, então, tem um documento com assinatura do Chico permitindo que as cartas dele fossem divulgadas, fossem tornadas públicas. Em decorrência, eu fui algumas vezes em Uberaba.

Demorei a escrever esse livro porque, com quatro filhos e muitas dificuldades, eu fazia tortas doces, tortas salgadas, bolos de aniversário por encomenda. Quando terminei de fazer os comentários da correspondência, marquei uma data especial, antes de entregar os originais à FEB, para que Chico visse o meu trabalho e aprovasse, dando, assim, a permissão daquilo também que eu estava abordando, comentando.

\footnotetext{
${ }^{6}$ A entrevistada se refere à Eurípedes Humberto Higino dos Reis que se autointitula filho adotivo de Chico Xavier. (sua adoção não foi reconhecida pela $1^{\text {a }}$ vara de família de Uberaba. Disponível em: https://www.rotajuridica.com.br/euripedes-humberto-higino-dos-reis-nao-consegue-ser-reconhecidocomo-filho-de-chico-xavier. Acesso em: 05 mar. 2021).
} 


\section{Sim, para saber se estava de acordo, não é?}

Mas, para minha surpresa, Chico marcou para fazer a leitura na casa dele, no horário de 20h. Nós fomos cedo e depois desse horário já estávamos na porta da casa dele, que nos recebeu carinhosamente. Entramos e ele nos levou para a sala, onde foi feita a leitura.

Em meio a muita emoção, sentamo-nos ao lado dele. Inicialmente expliquei como havia estruturado o livro. Foi uma coisa tão interessante, porque ele leu a primeira carta, e lia em voz alta! Ele ficou até mais de meia-noite lendo em voz alta. Acredita uma coisa dessa? Eu falava com ele: “Chico, quer que eu leia um pouco?” - "Não, pode deixar, que eu estou indo bem" e tal, mas ele começou a ler... ele lia o texto dele, depois é que ele relatava esse momento da carta, explicando o porquê de ter escrito isso, o que tinha acontecido, sem ler o meu comentário! Em seguida, ao ler meu comentário, quando ia lendo, ele se admirava, e dizia: "Suely, é como se você soubesse qual era o assunto!" Porque o meu comentário ele espraiava mais, se expandia, foi quando, então, ele falou que o próprio Dr. Wantuil estava me inspirando. E ele foi lendo, foi lendo, foi lendo, em sequência, quando já era perto da meia-noite, eu falei assim: “Chico, deixa eu ler um pouco para você.” Mas ele fazia questão, só depois começou a saltear os capítulos, antes ele estava indo na sequência. Eu tenho até foto disso, entendeu? Se você quiser, a gente ... é uma fotozinha (IMAGEM 2), muito simples em preto e branco, né?

\section{Imagem 1: Foto de Suely Caldas Schubert com Chico Xavier na apresentação do manuscrito de Testemunhos de Chico Xavier}

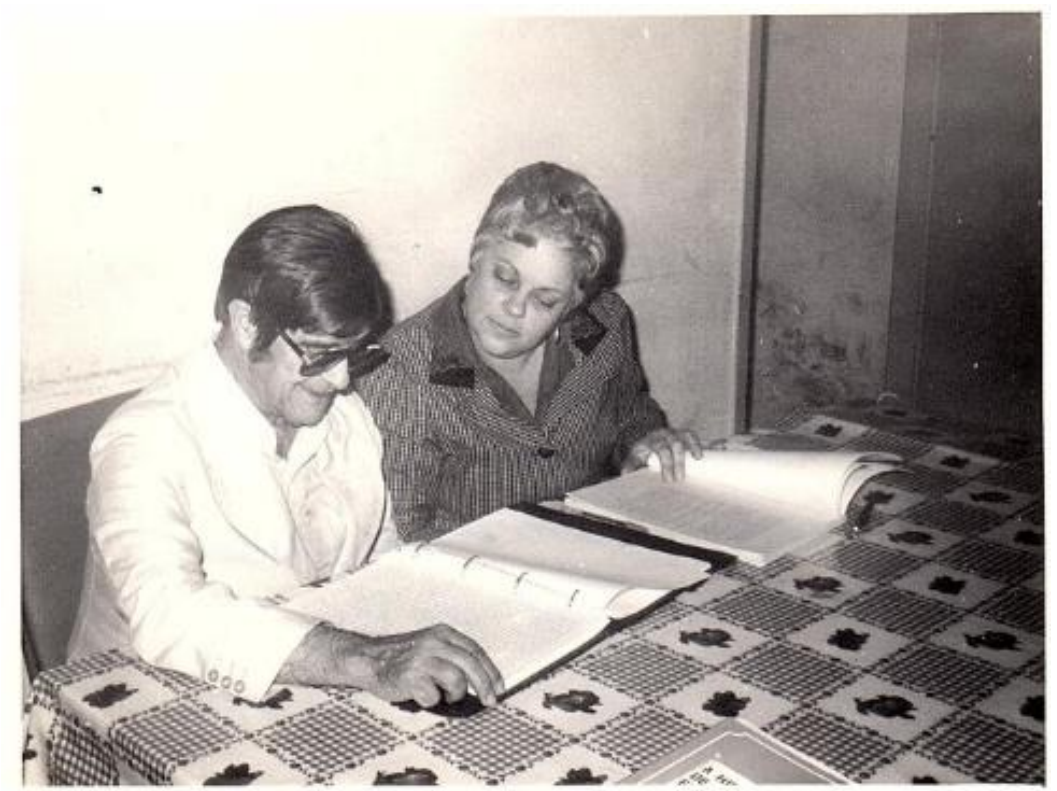

Fonte: Arquivo pessoal de Suely Caldas Schubert 
Então, ele ali lendo e sempre falando: "Mas, é incrível como você conseguiu captar o que era o assunto!" Eu fiquei muito feliz com isso e, depois da meia-noite e tanto, ele aprovou. Falou: “Olha, não preciso nem ver o resto!” Não chegou a ver ... mais ou menos uns $30 \%$ ele não viu.

11. Quando lemos Testemunhos de Chico Xavier, nos parece que o Chico, em alguns momentos, demonstrava tristeza por causa do assédio negativo que, às vezes, as pessoas ofereciam. Essa leitura é correta? Ele sentia tristeza com essas pessoas, ele lamentava? Como era essa relação com essa pressão que faziam em cima dele?

Olha, na verdade, naquela época, ele falava um pouco sim, e a gente notava, vamos dizer, uma compreensão daquilo que estava acontecendo. Isso era próprio dele, aquela ideia que o assédio negativo, ou uma perseguição, ou uma calúnia, eram de pessoas que estavam doentes. Quem faz um uma calúnia, o caluniador, é uma pessoa doente, que precisa de prece, que ... ele nunca passou disso.

\section{Mas isso o entristecia? Ele demonstrava tristeza por isso?}

Eu notava uma certa tristeza, mas o convívio era rápido. Por mais que eu fosse várias vezes, eram poucos minutos porque, às vezes, tinha fila. Por isso que, no dia que ele foi ler, vamos dizer, os originais, ele pediu para ser na casa dele, porque ficava bem tranquilo, bem sossegado. Não é? Então, eu senti que ele queria ver como eu havia abordado. Eu levei para que ele pudesse tomar conhecimento da obra.

13. Na nossa pesquisa, estou tentando classificar se podemos dizer que o Chico Xavier era um místico, não no sentido do misticismo, daquela coisa que Kardec condena na sua obra, mas uma mística do coração, aquela coisa, por exemplo, que se tem em Teresa D'Ávila, São João da Cruz, Inácio de Loyola, Albert Schweitzer, que eram pessoas que são consideradas hoje grandes místicos por causa desse amor, dessa pureza do coração, de dedicação do próximo, etc. ... A senhora, do seu ponto de vista pessoal, acha que ele pode ser comparável a esses místicos? Ele seria um místico? 
Não! Não acho não, porque, se colocar místico, muda o sentido da coisa, ele é um missionário. É diferente, não é? Místicos são esses outros, agora, se você colocar o Chico dentro dessa qualificação de místico, pode atrapalhar a imagem dele e da imensa e notável obra que realizou, porque ele não era um místico! Ele é um missionário. E a doutrina espírita, dentro da sua racionalidade... Que a doutrina é muito racional, não é?... Nós não temos isso de misticismo, assim. Agora as pessoas poderiam até, ao se aproximar dele, tendo essa noção que ele poderia ter uma coisa assim transcendental, diferente, né? Mas, na verdade, ele próprio e o meio espírita também não. Ele não é um místico, viu! A gente não qualificaria assim.

\section{Quando a senhora conversou com ele a respeito do livro, ele relacionava as leituras que fazia? Ele citou se gostava de um determinado autor que ele gostava de ler de uma forma particular?}

Não, eu lembro, sempre, o tempo todo ele falando de Emmanuel'! Emmanuel fala isso, Emmanuel fala aquilo, ele deve ter falado... Mas estou lembrando que de Kardec ele falava muito. Ele citava Kardec, especialmente o Evangelho Segundo o Espiritismo (KARDEC, 2013) e O Livro dos Espíritos (KARDEC, 2008), mas especialmente o Evangelho Segundo o Espiritismo, as citações.

Estar com Chico Xavier era um aprendizado muito grande. Certa vez, eu participei de um trabalho muito belo que ele fazia. Consistia numa visita às pessoas mais necessitadas, à noite, e era chamado de peregrinação. Eu fui convidada para participar também, eram só umas quatro ou cinco pessoas com ele, e chamou uma outra senhora (que está ainda encarnada, ela deve ter hoje 90 e tantos anos, ela mora em Ipanema, no Rio de Janeiro). Ela era de um centro espírita de Ipanema, creio que é a Benildes. Então ele chamou, eu não a conhecia, e ele chamou a Benildes e deu o braço a nós duas. A gente ia caminhando, porque não havia propriamente uma estradinha, via-se um caminhozinho, entendeu? Ali no meio do mato, entrava ali. Fomos caminhando... tinha uma certa... a iluminação... não era totalmente escuro, né? E então nós fomos. Chegamos ao local, que não era muito longe. Chegamos ao local, uma casinha muito humilde. Chico vai, faz prece, conversa com a pessoa. Isso é muito lindo. Ele fez isso muitos anos, chamava de peregrinação. Eu tive a felicidade de ir e assistir a isso. Então ele fazia uma prece, é como que aplicava o passe, passava a mão

\footnotetext{
${ }^{7}$ Emmanuel, segundo Chico Xavier, seria o nome do seu mentor espiritual, que o acompanharia desde 1931 orientando-o em sua missão. (SOUTO MAIOR, 2003, p. 43).
} 
na cabeça da pessoa, fazia um carinho assim nos ombros. Era um passe, né?! Então fazia prece e depois, antes de sair, colocava um trocadinho num cantinho, assim, sabe?... e colocava um dinheirinho também. Assim... eu nunca soube quanto, mas era alguma coisa que ele colocava ali, entendeu?

\section{Ele tinha assim, muita gente que podemos chamar de seguidores? Que eram mais próximo dele?}

Ah, tinha! Tinha! Especialmente, naquela época, era um número bem menor. Mas depois, quando eu voltei já escrevendo o livro, era muita quantidade, era muita gente, é ...

\section{O Chico era alegre?}

Alegre? Muito alegre, muito alegre, muito brincalhão, brincalhão mesmo! Uma vez que eu fui visitá-lo, e Divaldo ${ }^{8}$ estava lá também, aí foi aquela festa, ele com Divaldo.

Quando ia psicografar, ele entrava numa salinha, isso em Uberaba, e aquele salãozinho ${ }^{9}$ ali repleto, repleto! E então eu fui convidada a ficar à mesa das pessoas que iam comentar e Divaldo ficou em frente a mim e eu do lado de uma senhora, que depois eu soube, que era esposa do prefeito, era médium também, ficou psicografando. Chico ficava lá dentro, psicografando. Tinha pessoas sentadas pela janela, porque as janelas estavam abertas, as pessoas se sentavam, outros no chão, não tinha como. Depois é que vem o Chico para ler as cartas. Nessa hora é aquela seriedade do momento, mães aflitas, chorosas, cada uma pensando: “Será que eu vou merecer uma carta?” Aquelas que tinham realmente essa oportunidade ou essa benção de receber uma notícia de um parente querido estavam ali quando é um momento de emoção. Porque, na verdade, acabava emocionando todo mundo. Você vê, e você pensa que podia ser eu que estivesse ali também! Então era uma emoção muito grande. E nesse dia estava Divaldo, e Divaldo psicografou, acho, duas ou três mensagens também. Mas não propriamente cartas para as pessoas, porque os médiuns e os espíritos, especialmente os espíritos, eles têm uma ética fantástica, não seria o caso de Divaldo também ficar psicografando para as mães, esse é o trabalho do Chico! Divaldo

\footnotetext{
${ }^{8}$ Divaldo Pereira Franco nascido em maio de 1927 é um professor, médium, escritor, orador, e filantropo brasileiro.

${ }^{9}$ A entrevistada se refere ao pequeno salão do Grupo Espírita da Prece em Uberaba- MG.
} 
recebeu mensagens de outros espíritos, confortadoras, mas não direcionadas, porém de sentido geral, não direcionadas para qualquer pessoa.

\section{Eu queria escutar da senhora o seguinte: o quanto que ele se condoía com essas mães? Como é que ele falava disso?}

Porque isso é empatia, uma empatia muito grande que Chico sempre teve. Eu estava..., uma vez eu assisti a um caso muito interessante de um casal que chegou com o médico junto, e a gente, no primeiro momento, não sabia que era casal, um menino e o médico. O menino era autista. Só depois que o casal, o pai, começa a conversar com o Chico e a contar o caso, ele fala do menino e explica que o senhor do lado era um médico, o pediatra que tinha diagnosticado que era autismo. Os pais queriam saber... E o médico também era espírita, ainda tem esse detalhe, todos ali. Eles queriam saber se o diagnóstico e o tratamento estavam bem direcionados, se a orientação era correta, pois era mais raro àquela época os casos de autismo, e Chico vai explicar. Chico fala de uma forma muito interessante. Ele fala assim, que o autista, quase sempre, é um espírito que não quer voltar à carne, não quer reencarnar de maneira geral. Hoje a gente já sabe que existem muitos outros casos, mas, de forma geral, espírito não quer voltar, então é preciso, muitas vezes, que os pais conversem com o espírito da criança quando ela está adormecida, que eles o amam, que é bem-vindo. E falou com o médico que estava correto. Esse foi um atendimento muito interessante a que eu assisti. É essa compaixão dele, é uma empatia, porque, muitas vezes antes da pessoa chegar, ele já está sabendo, não é?

Ah, tem outra coisa interessantíssima que aconteceu comigo! Ele sabia dos meus pensamentos, do que eu estava fazendo em Juiz de Fora. Isso é uma coisa muito curiosa, imagina quanto tempo já tinha passado! Tinha um rapaz da cidade de Ubá, esse rapaz ia sempre à Uberaba, juntamente com o casal que era dono de uma empresa. Ocorre que eles eram muito amigos deste rapazinho. O rapaz tinha por volta dos quinze, dezesseis anos, naquela época, quando ele foi a primeira vez. Aconteceu que o Chico se tomou de cuidados e carinhos por ele. Ele era um menino que tinha algumas dificuldades, mas não assim tão visíveis, é que Chico percebia. Então esse rapazinho o Chico passou a proteger, inclusive chegou a dormir na casa do Chico. O casal ia, sempre o levava. Isso foi algumas vezes e o tempo passou e o rapaz continuava indo, ele casou, já com o emprego e as visitas aconteciam menos. 
E então depois, um belo dia, eu estava em casa, toca lá... chega alguém, era ele! E chegou sem voz, não falava, estava com um cadernão na mão. Tudo o que queria falar ele escrevia no caderno e falou para mim com gestos que ele estava sem voz. Então, escreveu no caderno que achava que era obsessão, que era um espírito obsessor e ele foi lá para me perguntar se eu podia lhe aplicar um passe. Eu o convidei a entrar, sentou na sala ali comigo e eu fiquei mentalizando o meu mentor. Resolvi atendê-lo por estar muito acostumada com ele, de muitos anos, ele muito trabalhador na casa espírita que frequentava, então sabia quem era, sua família, a esposa e filhos. Fomos para uma outra salinha menor e fizemos a prece, logo senti a presença do obsessor que imediatamente se comunica e começa a falar horrores dele, ele passa a dialogar com ele, com uma voz de falsete, pedindo perdão ao obsessor. Entretanto, o nosso irmão perseguidor não foi encaminhado. Mas ele ficou bem aliviado e já não estava mais com a voz de falsete, porque fez muito esforço para falar e agradeceu e foi embora.

Acontece que, daí uns dias, ele foi a Chico Xavier com o tal do casal ainda, o casal naqueles anos todos continuou a levá-lo, o que foi bom. Eu não estava sabendo! Vinte dias depois, mais ou menos, quase um mês, ele me aparece lá em casa falando normalmente. Ele chegou e falou: "Suely, eu vim te contar uma coisa, que eu não vim antes porque não pude" ... um dos meninos dele tinha adoecido. Ele falou assim: "Eu não vim antes porque eu não pude, mas eu cheguei lá e... você não vai acreditar! Antes de eu falar qualquer coisa com o Chico, ele olhou para mim e falou assim: 'Sabe aquela reunião mediúnica que você fez lá na casa da Suely, sabe aquele espírito?'... e contou a história toda do espírito, como teria sido o passado, como as coisas aconteceram.” Agora, importantíssimo foi ele saber que nós fizemos uma reunião, que o espírito comunicou, que ele estava sem voz. Ele não sabia de nada! Quer dizer, é... assim, na realidade, ele não sabia, mas espiritualmente ele captou isso tudo, né? Então ele que ajudou o espírito a ser encaminhado. E aí o rapaz foi curado para todo o sempre (risadas)... ainda está, até hoje. Mas agora ele está com mais idade e está quase cego e com muita dificuldade.

\section{Vou fazer uma pergunta meio óbvia: Chico Xavier colocava a doutrina espírita acima de tudo na vida dele?}

Tudo! Completamente! Totalmente, porque Emmanuel era assim! E outra coisa, Emmanuel falava com as pessoas: "Se algum dia eu deixar Jesus e Kardec, não fiquem comigo! Vão procurar outras pessoas, porque nosso caminho é Jesus e Kardec”. Emmanuel 
sempre foi de citar muito Jesus e Kardec. E é bom dizer: falar que Chico é Kardec não tem nenhum cabimento. Você sabe disso, né ${ }^{10}$ ?

\section{A senhora faz um relato no livro sobre a questão de Os quatro evangelhos de Roustaing (SCHUBERT, 1991, p. 87). Há pessoas que criticam o Chico, chamando-o de Roustangista, de forma até pejorativa. O que a senhora pensa sobre isso?}

Foi bom você abordar isso, porque no meu livro Testemunhos de Chico Xavier tem referência a Roustaing ${ }^{11}$.

\section{2o. Sim, é por essa razão que estou perguntando.}

Quando eu fui ao Chico para pedir permissão para escrever o livro - conforme o que eu combinei com a FEB, que eu ia lá pedir autorização -, um dos pontos que mencionei foi que algumas cartas têm referência a Roustaing. Disse ao Chico: "você não fala assim abertamente, você aceitou aquilo”. Sabe o que ele respondeu? "Ah, minha filha, nessa altura da minha vida, deixa o povo falar. Pode por. Deixa o povo falar!” Então, na verdade, ele também ficou meio que em cima do muro. E eu fiquei mais que em cima do muro, mas não adiantou não, porque eu fui taxada de Roustanguista durante muitos anos.

\section{Tem gente que fala que o Espiritismo não é religião, o Chico falava abertamente sobre esse aspecto religioso do Espiritismo?}

\footnotetext{
${ }^{10} \mathrm{~A}$ entrevistada se refere a uma forte especulação no meio espírita a respeito da possibilidade de Chico Xavier ter sido uma reencarnação de Allan Kardec. Dentro do movimento espírita, a especulação virou polêmica. Dividiram-se as opiniões, e, de lado a lado, esgrimiram-se argumentos contrários. Os jornais espíritas passaram a veicular pontos de vista; o assunto vem sendo trabalhado nos grupos de estudos doutrinários, e os caminhos da internet estão recheados de artigos, estudos, pesquisas sobre o assunto. Disponível em: https://www2.sbee.org.br/index.php?option=com_content\&view=article\&id=44:a-reencarnacao-de-allankardec\&catid=13\&Itemid=101. Acesso em: 05 mar. 2021.

${ }^{11}$ Jean-Baptiste Roustaing (1805 - 1879) foi um espírita francês coordenador da obra Les Quatre Évangeles Spiritisme Chrétien ou Révélation de la Révélation ("Os Quatro Evangelhos ou Revelação da Revelação/Os Quatro Evangelhos - Espiritismo Cristão ou Revelação da Revelação"), obra psicografada pela médium belga Émilie Collignon. Essa obra é objeto de grande divisão e discussão entre os espíritas, desde o seu lançamento em 1866 em Paris, em razão de seu conteúdo ser eventualmente contraditório em relação à obra de Allan Kardec. A Federação Espírita Brasileira (FEB) foi cobrada, por muito tempo, por alguns seguimentos do movimento espírita, por manter e divulgar as edições dessa obra que tantos problemas trouxe à coesão do Espiritismo desde o seu lançamento. Tais questões foram, inclusive, objeto de decisão judicial, em 10 de agosto de 2019, que autorizou a retirada da divulgação da obra de Roustaing dos objetivos da FEB. Disponível em: https://www.febnet.org.br/blog/geral/noticias/ata-da-assembleia-geral-extraordinaria-dos-sociosefetivos-da-feb/. Acesso em: 05 mar. 2021.
} 
Muito, porque os livros do Emmanuel falam isso, né? No Pinga Fogo ${ }^{12}$ também ele fala muito. Então ali, no Pinga Fogo (XAVIER, 1984), você tem um material maravilhoso!

\section{2. É, eu tenho transcrito toda a entrevista deles!}

É um material maravilhoso, né?

\section{Então, podemos dizer que o Chico realmente acreditava que o Espiritismo é uma religião?}

É, realmente, realmente!

Agora, o Chico a respeito de ele ser $\operatorname{Kardec}^{13}$, não é, então, não tem o menor fundamento! Porque a mente de Kardec é completamente diferente da do Chico, mais científica, filosófica, a mente de Kardec. E Chico é aquela mente totalmente voltada para o evangelho, um ser totalmente evangelizado e veio evangelizar as outras pessoas, não é? Então Chico é assim, evangelho, é o tempo todo evangelho. Sofreu muito com os problemas familiares, com o sobrinho ${ }^{14}$, e muitas outras coisas de maneira que Chico era assim. Eu não tenho mais coisas para falar, que eu o encontrei pouco!

\section{Então, podemos dizer que, pela percepção da senhora, que o Chico - só para deixar claras suas últimas frases -, que ele era, então, muito mais intuitivo do que razão, ele era muito mais coração?}

Sim, mas eu acho que era os dois, porque Chico também é de uma inteligência colossal, uma inteligência fantástica. O Chico é uma inteligência a nível de Emmanuel. E com respeito à mediunidade, eu estou escrevendo um novo livro sobre Chico agora, e nesse livro eu estou analisando, num dos capítulos, a mediunidade de Chico Xavier. Porque a

\footnotetext{
${ }^{12}$ No dia 28 de julho de 1971, o médium mineiro foi o responsável por uma das maiores audiências da TV brasileira com o Programa Pinga Fogo da extinta TV Tupi, exibição na qual 75\% dos televisores paulistas acompanharam o programa até as $3 \mathrm{~h}$ da manhã. (SOUTO MAIOR, 2003, p. 191).

${ }^{13}$ Entrevista volta a fazer referência à polêmica em torno de Chico Xavier ser a reencarnação de Allan Kardec. Ver nota 11.

${ }^{14}$ Especula-se que ações do sobrinho de Chico Xavier teriam sido a razão de ele ter deixado Pedro Leopoldo e mudar para Uberaba. Disponível em:

https://www.em.com.br/app/noticia/gerais/2017/o6/25/interna_gerais,878878/grande-bh-e-triangulomineiro-guardam-memoria-viva-de-chico-xavier.shtml. Acesso em: 05 mar. 2021.
} 
mediunidade de Chico Xavier é de altíssimo nível, como nunca se viu, entendeu? Então, analisando especialmente o livro Há 2000 anos (EMMANUEL, 1996) e Paulo e Estevão (EMMANUEL, 2020). São duas obras fantásticas, viu?!

25. No Pinga Fogo, que a senhora citou, o Chico diz que Emmanuel pediu para ele meditar por uma hora, para depois escrever por uma hora. O que mais que a senhora comentaria sobre isso? A senhora sabe se ele meditava muito, se ele se recolhia muito para orações?

É, mas, claro... O Chico vivia, vamos dizer, 24 horas praticamente evangelho. O tempo todo. Ele tinha a parte, claro, do campo físico, da vida física, da vida material, tanto que ele trabalhava para o seu sustento, ajudando sempre o próximo, essa coisa toda. Mas a mente e o contato era o tempo todo, o tempo todo o contato espiritual. Então eu dei o título de "Chico e Emmanuel - Vínculo de Luz”. Então é isso, né!?

26. Agradeço a senhora pela disponibilidade, e já estou ansioso para ler esse novo livro. Muito obrigado.

Muito obrigada, espero que eu tenha sido útil.

\section{REFERÊNCIAS}

EMMANUEL (Espírito). Há 2000 anos... Psicografado por Francisco Cândido Xavier. 29. ed. Rio de Janeiro: FEB, 1996.

EMMANUEL (Espírito). Paulo e Estevão. Psicografado por Francisco Cândido Xavier. 45. ed. Brasília: FEB, 2020.

KARDEC, Allan. O Livro dos Espíritos. Tradução Guillon Ribeiro. 91 ed. Rio de Janeiro: FEB, 2008.

KARDEC, Allan. O Evangelho Segundo o Espiritismo. Tradução Evandro Noleto Bezerra. 2 ed. Brasília: FEB, 2013.

SCHUBERT, Suely Caldas. O semeador de estrelas. Salvador: Livraria Espírita Alvorada, 1989.

SCHUBERT, Suely Caldas. Testemunho de Chico Xavier. 4. ed. Brasília: Federação Espírita Brasileira, 2010. 
SCHUBERT, Suely Caldas. Obsessão/Desobsessão: Profilaxia e Terapêutica Espíritas. 13. ed. Rio de Janeiro: Federação Espírita Brasileira, 1999.

SCHUBERT, Suely Caldas. Divaldo Franco: uma vida com os Espíritos. Salvador: Leal, 2006a.

SCHUBERT, Suely Caldas. Transtornos Mentais: uma leitura Espírita. Belo Horizonte: Minas Editora, 2006b.

SCHUBERT, Suely Caldas. Os poderes da mente. 3. ed. São Paulo: EBM Editora, 2010.

SCHUBERT, Suely Caldas. Dimensões espirituais do Centro Espírita. 2. ed. Rio de Janeiro: Federação Espírita Brasileira, 2012.

SOUTO MAIOR, Marcel. As vidas de Chico Xavier. São Paulo: Planeta, 2003.

XAVIER, Francisco Cândido. Chico Xavier no Pinga Fogo. São Paulo: Edicel, 1984.

Recebido em: 23 de mar. 2021 Aprovado em: 28 mai. 2021 